\begin{tabular}{c} 
International Journal of Biological Research, 2 (2) (2014) $153-155$ \\
International Journal of Biological Research \\
Journal home page: $\begin{array}{c}\text { www.sciencepubco.com/index.php/IJBR } \\
\text { doi: } 10.14419 / j \mathrm{jbr.v2i2.3592} \\
\text { Research Paper }\end{array}$ \\
\hline $\mathrm{SPC}$
\end{tabular}

\title{
Haemoglobinuria due to hypophosphataemia in last trimester pregnant buffalo
}

\author{
B.Soma Sekhar Reddy ${ }^{1}$, B.Sudhakara $\operatorname{Reddy}^{2}$, R.Venkatasivakumar ${ }^{1}$, S.Sivajothi ${ }^{3 *}$ \\ ${ }^{1}$ Assistant Professor, Department of Veterinary Medicine \\ ${ }^{2}$ Assistant Professor (Veterinary Medicine), Teaching Veterinary Clinical Complex \\ ${ }^{3}$ Assistant Professor, Dept. of Veterinary Parasitology \\ College of Veterinary Science, Sri Venkateswara Veterinary University, \\ Proddatur-516360, Y.S.R.District, Andhra Pradesh, India. \\ *Corresponding author E-mail: sivajothi579@gmail.com
}

\begin{abstract}
A buffalo in her last trimester pregnancy was referred to clinic with signs of anorexia, voiding dark red coloured urine, dullness, mild diarrhoea and depression. It was diagnosed as an acute case of parturient haemoglobinuria by assessing the serum biochemical parameters. It had low levels of serum protein, albumin and phosphorous. Haemogram revealed decreased erythrocyte count, haemoglobin and haematocrit. The buffalo had been treated with phosphorous supplements and other supportive therapy.
\end{abstract}

Keywords: Buffalo, Last Trimester Pregnancy, Haemoglobinuria, Hypophosphataemia.

\section{Introduction}

Post parturient haemoglobinuria described as an acute disease in high yielding buffaloes and cows associated with hypophosphataemia and characterized by intravascular haemolysis. Hypophosphataemia results in decreased red blood cell glycolysis and ATP synthesis. Low levels of ATP predispose red blood cells to altered structure and function, and an increase in fragility and haemolysis, with resultant haemoglobinaemia and haemoglobinuria (Singari et al. 1991). The possible risk factors for development of post parturient haemoglobinuria includes ingestion of cruciferous plants, saponin from berseem, dietary phosphorous deficiency, decreased serum copper, selenium levels and increased molybdenum levels (Radostits et al. 2007 \& Brechbuhl et al. 2008). Parturient haemoglobinuria was recorded in buffalo rearing countries in India, Pakistan, and Egypt (Pirzada and Hussain 1998). Reports' regarding the incidence of post parturient haemoglobinuria in last trimester pregnant buffaloes was not recorded in Andhra Pradesh of India. This case report records the acute haemoglobinuria associated with hypophosphataemia in a buffalo in its last month of pregnancy and its management.

\section{Case history and observations}

Non-descriptive buffalo was referred to the Teaching Veterinary Clinical Complex, College of Veterinary Science, and Proddatur with a complaint of in appetence, voiding dark red coloured urine since two days in the last trimester pregnancy. On clinical examination of buffalo, pale conjunctival mucous membranes, passing of dark red coloured frothy urine (Fig.1), mild diarrhoea and normal ruminal motility $(3 / 2 \mathrm{~min})$ were recorded. Vital signs were recorded (Temperature, respiration and pulse were recorded as $101.1^{\circ} \mathrm{F}, 28$ breaths/min and $61 / \mathrm{min}$ respectively). Whole blood with addition of EDTA for haemogram, serum for biochemical analysis, peripheral blood smear for haemoprotozoan parasites, dung sample for screening of parasitic ova, urine sample for examination with urocolor strips were collected. Laboratory procedures were in accordance with previous studies (Sivajothi et al. 2014a; Reddy et al. 2014a).

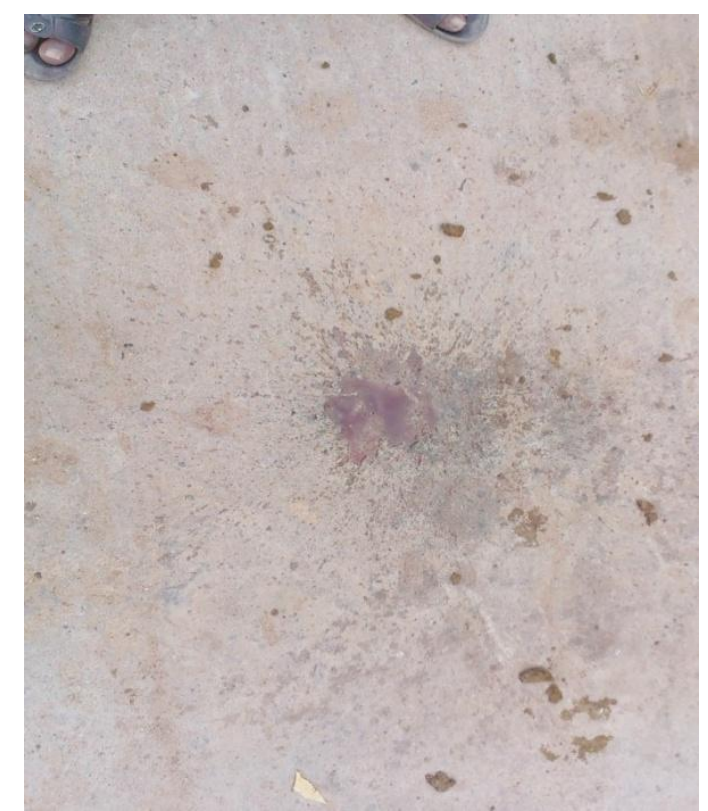

Fig. 1: Buffalo Passing the Reddish Colour Urine.

Haematology had total erythrocyte count $\left(3.9 \times 10^{6} / \mu \mathrm{L}\right)$, haematocrit $(22 \%)$, haemoglobin $(5.45 \mathrm{~g} / \mathrm{dL})$, total leucocyte count 
(12520/ $\mu \mathrm{L})$, lymphocyte percentage (66\%), neutrophil percentage $(32 \%)$, eosinophil percentage $(2 \%)$. Serum had total protein $(6.48$ $\mathrm{g} / \mathrm{dL})$, albumin $(1.89 \mathrm{~g} / \mathrm{dL})$, phosphorus $(2.26 \mathrm{mg} / \mathrm{dL})$, calcium $(9.8 \mathrm{mg} / \mathrm{dL})$, copper $(114 \mu \mathrm{g} / \mathrm{dL})$, aspartate aminotransferase (39 $\mathrm{u} / \mathrm{L})$, creatinine $(1.8 \mathrm{mg} / \mathrm{dL})$ blood urea nitrogen $(63 \mathrm{mg} / \mathrm{dL})$ and total bilirubin $(3.89 \mathrm{mg} / \mathrm{dL})$ levels. Urine was dark red in colour (Fig.2). Urine of haemoglobinuric buffalo was positive for urobilinogen, bile salts and ketone bodies, haemoglobin and albumin (Fig.3). Microscopic examination of urine of revealed no intact erythrocytes but few epithelial cells and crystals were observed. Dung revealed presence of severe amphistome spp. ova. Blood did not reveal any haemoprotozoans.

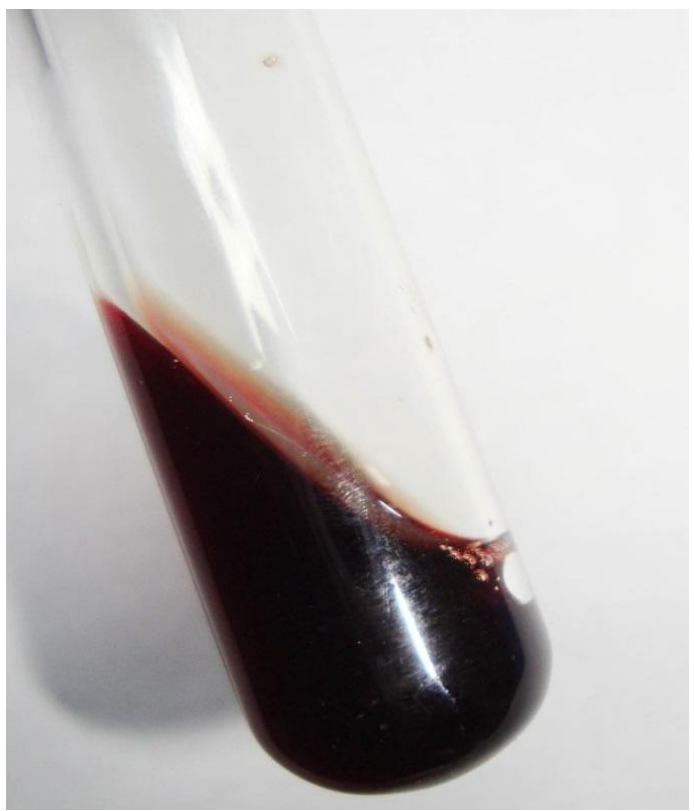

Fig. 2: Reddish Colour Urine.

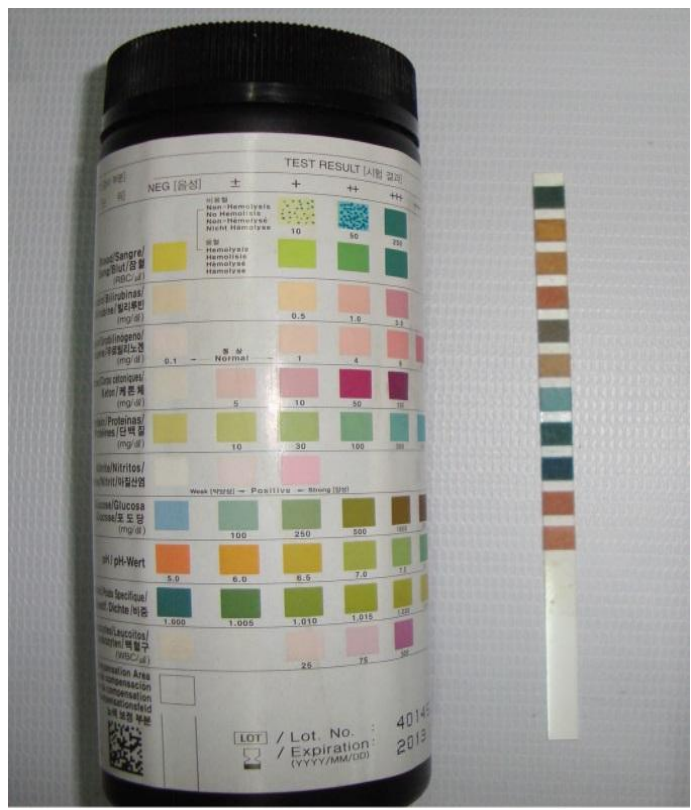

Fig. 3: Examination of the Urine with Urocolor strips

\section{Treatment and discussion}

Buffalo was suffering with haemoglobinuria due to hypophosphataemia. So, it was treated with phosphorous supplementation and supportive therapy. Buffalo was treated with $20 \mathrm{ml}$ of tonophosphan (sodium salt of 4-dimethylamino- 2methylphenyl phosphinic acid) administered for 5 days intravenously and 20\% dextrose along with the electrolytes (Intalyte @
$2000 \mathrm{ml}$ ) were given intravenously for three days. Haemotinic injection (Feritas) was given @ of $10 \mathrm{ml}$ intramuscularly weekly twice and advised feritas boli @ 2 /day for 5 days. After two days of above therapy oxyclozanide @ $18 \mathrm{mg} / \mathrm{kg}$ body weight was given once orally. After therapy, recovery signs like discoloration of urine to normalcy, improved appetite, and activeness of the buffalo were observed.

The present case report of nutritional haemoglobinuria was recorded in buffalo which is in $6^{\text {th }}$ lactation. It may be due to lactational stress as the number of lactations increases. Hypophosphataemia in the present case may be due to inadequate supplement of phosphorous. In this study observed signs in accordance with the (Muhammad et al. 2001). Observed lowered serum phosphorous $(2.26 \mathrm{mg} / \mathrm{dL})$ suggestive of hypophosphataemia. Similar low phosphorous levels in parturient Haemoglobinuria cases were reported by Iqbal et al. (2011) $(2.2 \mathrm{mg} / \mathrm{dL})$.

Recorded haematological parameters were deviated from the apparently healthy animals in our local areas (Sivajothi et al. 2014b; Reddy et al. 2014b). Decreased haemoglobin concentration, haematocrit and erythrocyte count indicative of anaemia. These findings were in association with the previous reports on haemoglobinuria in buffaloes (Mahmood et al. 2013). Hypoproteinemia, hypophosphataemia, higher levels of blood urea nitrogen, creatinine and bilirubin levels were recorded in this case study. Heinz bodies were not detected on stained blood smears of affected buffalo. Previously Heinz body formation in erythrocytes of haemoglobinuric animals have been reported (Radostits et al. 2007). Studies reported, Heinz body formation in erythrocytes of haemoglobinuric animals is associated with hypocuprosis. In the present study, hypocuprosis was not recorded which might be the reason for absence of Heinz bodies in erythrocytes.

Clostridial toxins, leptospira organisms could not be screened due to certain constraints in the laboratory. But, present case was diagnosed as haemoglobinuria due hypophosphataemia based on the serum phosphorous analysis and response to the therapy.

Many reports regarding the post parturient haemoglobinuria immediately after calving were reported in bovines. In the present study, haemoglobinuria was recorded in advanced pregnant buffalo which is a rare report. It may be due to buffaloes in advanced gestation, more phosphorus and calcium are required for the developing foetus if supplementary phosphorus is not provided, thereby leading to hypophosphataemia. Moreover, high calcium to phosphorus ratio results in decreased phosphorus absorption from the intestinal tract and ultimately leads to hypophosphataemia. Although many soils are naturally deficient in phosphorus, heavy leaching by rain and constant crop removal also contribute to phosphorus deficiency in soil (Digraskar et al. 1991).

\section{Conclusion}

Present report on acute onset of haemoglobinuria due to hypophosphataemia in last trimester of a buffalo.

\section{References}

[1] Brechbuhl M, Meylan M, Kunz-Kirchhofer C, Bodmer M, Michel A, Kaufmann T (2008) Post-parturient haemoglobinuria in cows kept in the Swiss Alpine region. Tierarztliche Praxis Ausgabe G: Grosstiere Nutztiere 36 (4): 236 - 240.

[2] Digraskar S, Singh B, Deshpande BB (1991) Epidemiology and clinico-pathology of haemoglobinuria in buffalo (Bubalus bubalis). Livestock Advisor, 16: 32-38.

[3] Iqbal A, Mustafa G, Tripathi AK, Soodan JS (2011) Post parturient Haemoglobinuria in a buffaloe-a case report. International Journal of Livestock research. Vol.1:59-63.

[4] Mahmood A, Khan MA, Younus M, Khan MA, Ahad A, Ahmad M, Iqbal HJ, Fatima Z, Anees M (2013) Haemotological and biochemical risk factors of parturient Haemoglobinuria in buffaloes. Journal of Animal and Plant Sciences, 23(2):364-368. 
[5] Muhammad G, Saqib M, Athar M (2001) A rational approach to diagnosis, treatment and control of parturient haemoglobinuria (red water) in buffaloes and cattle. Pakistan Veterinary Journal, 21: 214- 219.

[6] Pirzada WH, Hussain SZ (1998) Parturient haemoglobinuria in buffaloes- A review, Tropical Animal Health and Production, 30: 209- 215. http://dx.doi.org/10.1023/A:1005095410576.

[7] Radostits OM, Blood DC, Gay GC (2000) Veterinary Medicine. A Textbook of the Diseases of Cattle, Sheep, Pigs, Goats and Horses. W.B. Saunders. PP: 1452-1462. Veterinary Medicine. 9th Edn. ELBS, Bailliere and Tindall, London.

[8] Reddy LSSVP, BS Reddy, BR Naik and CS Prasad (2014a) Haematological and clinical alterations with traumatic reticuloperitonitis in cattle. International Journal of Veterinary Science, 3(4): 203-205.

[9] Reddy BS, Reddy BSS, Reddy YVP, Vennkatasivakumar R (2014b) Nervous form of ketosis in cows and its treatment, International Journal of Biological Research, 2 (2) (2014) 143-144, DOI: 10.14419/ijbr.v2i2.3591.

[10]Singari NA, Bhardwaj RM, Chugh SK, Bhandwaj S (1991) Status of erythrocytic glucose-6-phosphate dehydroginase (G6PD) in phosphorous deficiency Haemoglobinuria of buffaloes. Indian Veterinary Journal, 68:226-230.

[11]Sivajothi S, Rayulu VC, Reddy BS (2014a) Detection of Trypanosoma evansi by different methods in bovines in Andhra Pradesh. The Journal of Advances in Parasitology, 1(3):35-38. http://dx. doi.org/10.14737/journal.jap/2014/1.3.35.38.

[12] Sivajothi S, Reddy BS, Kumari KN, Rayulu VC (2014b) Haematological changes in Trypanosoma evansi infected cattle. International Journal of Scientific World, 2(1):27-30. DOI: 10.14419/ijsw.v2i1.2275. 